\title{
Empirical Analysis of the Contribution of the Aviation Industry to the Nigerian Economy
}

\author{
Mobolaji S. Stephens \\ Department of Transport Management Technology, \\ Federal University of Technology, PMB 704 Akure, Nigeria \\ Vivian Ikeogu \\ Transport Management Technology, \\ Federal University of Technology, PMB 1526 Owerri, Imo Nigeria \\ Omatshola B. Stephens \\ Department of Transport Management Technology, \\ Federal University of Technology, PMB 704 Akure, Nigeria \\ Wilfred I. Ukpere \\ Department of Industrial Psychology \& People Management, \\ Faculty of Management University of Johannesburg, South Africa \\ Corresponding email: wiukpere@uj.ac.za or wilfredisiomaukpere@gmail.com
}

\section{Doi:10.5901/mjss.2014.v5n3p115}

\begin{abstract}
The study revealed the contribution of the Nigerian Aviation Industry to the National GDP of Nigeria. To this end we determined the performance of the aviation workers with regards to contribution to national GDP; determined the performance of the Nigerian labour force's contribution to the GDP and did compared the contribution per head of aviation workers to the aviation industry's revenue of aggregated product; we ascertained the aviation industry's percentage contribution to the National GDP and did forecasted the growth of the GDP, aviation industry and its workers' contribution to GDP. To achieve what we did we used secondary data obtained from the National Bureau of Statistics from 1985 to 2012 for National GDP; aviation industry's contribution to the GDP; the annual estimates of Nigerian labour force; the annual estimates of labours employed in the aviation industry; the annual throughput and revenue in the industry. We were able to determine that an average aviation industry worker is more productive than an average member of the Nigerian Labour force as a whole. We found that the aviation industry's contribution to National GDP is very small, but noted that it contributes a lot towards ensuring the smooth flow of foreign direct investment (FDI) into Nigeria. We were able to forecast that the industry will grow at about $25.4 \%$ rate on annual basis. We also discovered that in the contribution of the Transport Sector as a whole to National GDP, aviation industry made the least contribution, while road transport made the most. Road transport could even make more if all the informal sectors of the road transport mode are accounted for. Aviation industry is great and serves as a great face-lift for the nation, however, it serves less than $10 \%$ of the population and contributes less than expected, judging from the capital investment involves in the sector. We therefore suggest that land based transportation and their associated systems should be upgraded and more attention should be paid to them.
\end{abstract}

Keywords: Aviation industry, Contribution, Development, Economy,

\section{Introduction}

For many decades, the aviation industry has played a significant role in developing economies around the globe. It is reported that there are over two thousand $(2,000)$ airlines operating more than twenty-three thousand $(23,000)$ aircraft that serves about three thousand seven hundred $(3,700)$ airports around the world (Aerospace Global Report, 2011). This makes the industry the gateway to any economy aspiring to develop, enabling globalization, trade facilitation and tourism development. It is very crucial in the promotion of foreign direct investment (FDI) (Ladele, 2012). One can therefore say that the industry is crucial to the growth of the economy and national development. Ladele (2012) in her 
study of FDI, noted that as the emerging economies grow, their demand for air transportation will grow as their citizens becomes more financially empowered with increased disposable income. Development of air transport infrastructures in these emerging economies will further fuel the growth of the industry. However, Stephens (2011) noted that even with the growth, less than $10 \%$ of the population will still be able to afford air travel as the gap between the rich and the poor is rapidly expanding, which prompted him to call for more investment in the land-based transportation.

Stephens (2009) forecasted that the Nigerian Civil Aviation industry will keep growing at an average of $15 \%$ domestic traffic so that by 2019 an estimated 12,461,043 million passenger will be carried domestically. An industry with this growth rate should be of great interest. Moreover, it is expected to be a crucial industry in general economic growth promotion for any nation. Therefore, the level of the importance of this industry is best appreciated if its contribution to the gross domestic product (GDP) is measured. The analysis will be more meaningful if the industry's labour force contribution is measured and its significance is assessed in relation to those of other industry in the economy.

\section{Objectives of the Study}

The aim of the study is to evaluate the roles of local aviation industry in the Nigeria economy. In view of this, the study will also attain the following specific objectives:

- Determine the performance of aviation workers with regards to contribution to national GDP.

- To determine the performance of the Nigerian labour force's unitary contribution to the GDP and compare if the aviation industry had a better contribution per head when referenced against the labour force.

- To ascertain aviation industry percentage contribution to the national GDP.

- To forecast the growth of the traffic throughput and GDP, aviation industry and aviation workers' contribution to GDP and their performance within the industry.

- To conduct a reverse regression into the past to enable us compares the actual values of the past and the predicted values that could have happened in the past.

\section{Research Questions}

To make the objectives of the research realisable, and its objectives visible, certain questions arose. The questions which are tilted towards attaining the objectives of this research are as follows:

- What is the contribution per head of the aviation workers to the aviation industry's revenue and to the national GDP?

- What is the contribution per head of an average Nigerian worker to the national GDP?

- What is the aviation industry's contribution to the national GDP?

- What will be the future growth of the GDP, aviation industry and the aviation workers' contribution to GDP and their performance within their industry?

\section{Research Hypotheses}

In order to facilitate data collection so as to arrive at the correct conclusion, the following hypotheses will be used to guide this study:

\subsection{Hypothesis One}

- $H_{0}$ : The Aviation Industry is a major force towards the build-up of the national GDP.

- HI: The Aviation Industry is not a major force towards the build-up of the national GDP.

\subsection{Hypothesis Two}

- $H_{0}$ : The Nigeria airline business environment will improve even without liberalization being embraced.

- $\mathrm{H}_{1}$ : The Nigeria airline business environment will not improve except the policy of liberalization is embraced 


\subsection{Hypothesis Three}

- Ho: Workers of the aviation industry are more productive than their counterparts in the Nigeria Labour Force put together.

- $H_{1}$ : Workers of the aviation industry are not more productive than their counterparts in the Nigeria Labour Force put together.

\section{Significance of the Study}

The study will be of benefit to all stakeholders in the Aviation sector particularly the Airline Operators, the travelling public and the Governments of Nigeria. The need to ensure adequate infrastructural development and control over air safety by following the ICAO Standards and Recommended Practices strictly in other to ensure the sustainability of local airlines contribution to economy development will be the focus of this study. The gradual approach to liberalisation in the form of intra and extra regional co-operation will be highlighted with a view to assisting the Government via the regulator to develop the political will to implement and sustain the provisions of the Yamoussoukro decisions.

The Airlines will find the study useful as they may find sense in mergers and acquisition in order to compete favourably with the big airlines in the advanced economies of the world and join the "global alliance" groupings. Also the study will help to enhance the contemporary issue of billing, aviation fuel price and business models of airlines as it affect airlines role in their contribution to their primary economy.

\section{Research Methodology and Design of the Study}

The study is designed to reveal the contribution of The Nigerian Aviation industry to the National GDP of Nigeria with a view to:

- Determine the performance of aviation workers with regards to contribution to national GDP.

- To determine the performance of the Nigerian labour force's unitary contribution to the GDP and compare if the aviation industry had a better contribution per head when referenced against the labour force.

- To ascertain aviation industry percentage contribution to the national GDP.

- To forecast the growth of the GDP, aviation industry and the aviation workers' contribution to GDP and their performance within their industry.

\subsection{Area of Study}

The area under study is the Nigerian Aviation Industry as aggregated data on all the airlines and airports in Nigeria were collected for the research. Data on the Nigerian Labour Force was also collected.

\subsection{Samples}

The period covered by this study was between January 1985 - December 2012 being the period covered by data collected for aggregated industry's output and the national GDP.

\subsection{Method of Data Collection}

Research data were sourced from the National Bureau of Statistics annual publications, which were obtained from their website. The data collected span the period of 28 years from 1985 to 2012 and extracts for 2013 were also collected. Data collected were revenue/GDP contribution for the aviation industry; the aviation industry's throughput; national GDP of Nigeria and labour force records.

\subsection{Data Analytical Tools}

To analyse the data generated the MegaStat program was used to perform the regression analysis which was to forecast future levels of traffic throughput and GDP, aviation industry revenue/contribution to GDP and the traffic throughput in the aviation industry. Simple analytical tools like percentage and ratio was used to determine contributions and performance 
of the aviation workers, Nigerian Labour force, and the Aviation Industry as an integral part of the national GDP.

\subsection{Regression Analysis}

A Durbin-Watson Statistic output was sourced all at 95\% Confidence Level using throughput as the $Y$ variable and revenues and GDP as the $X$ variables. This simply means that with the knowledge of the aviation industry's revenue and throughput one can determine the future levels of national GDP.

\subsection{Limits and limitations}

The research work is limited to the domestic aviation industry, aggregating revenue of airlines and the airports. More extensive work could have been done but time is a limiting factor.

\section{Theoretical Framework, Result and Discussion}

The data presentation will follow a pattern that will present data collected and analyse same in the manner that the objectives of the study and research questions were presented and asked in the introduction (chapter one) of this research work.

\subsection{Aviation Workers Performance}

The domestic air network structure in Nigeria has so far linked only the state capitals, though not all state capitals are connected by air at this moment (Stephens, 2009). State capitals without air links are Abakaliki, Abeokuta, Ado-Ekiti, Awka, Bauchi, Birnin-Kebbi, Ebonyi, Gombe, Katsina, Lafia, Lokoja, Oshogbo, Umuahia, Uyo, Yenogoa, Yobe and Zamfara. Reasons for their lack of airports range from proximity to capitals with large airports to lack of market potentials. The number of routes that link each airport varies depending on the level of demand. Stephens (2009) used this to classify the airports into two categories, namely those with total number of routes less than the average number of eight (8) routes (low hierarchy) and those with above average number of routes (high hierarchy). These are shown in figures 1 and 2.

From figure 1, which shows the sixty-three (63) routes that make up the major routes, it is obvious that Lagos airport is the main air hub in Nigeria which is reflected by the clustered air routes. Abuja, Kano and Port Harcourt airports are other sub-hubs. Lagos, Abuja, Kano, Port Harcourt and Calabar airports are all international airports. It is no coincidence that Lagos, which is the commercial hub and Abuja, capital of Nigeria, Kano and Port Harcourt cities are strong centres of administrative, commercial and industrial activities in Nigeria. Figure 2, shows the network of 51 minor routes that are mostly served by helicopters and small aeroplanes. These routes also serve as feeder routes to the major routes and help buttress the importance of the aviation industry in the Nigerian economy.

Figure 1: Major domestic air routes in Nigeria

Source: Stephens (2009)

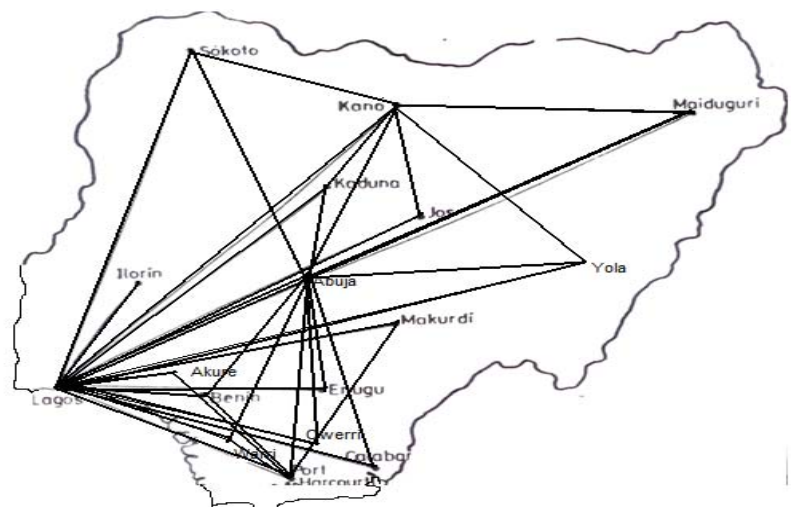


Figure 2: Minor domestic air routes in Nigeria

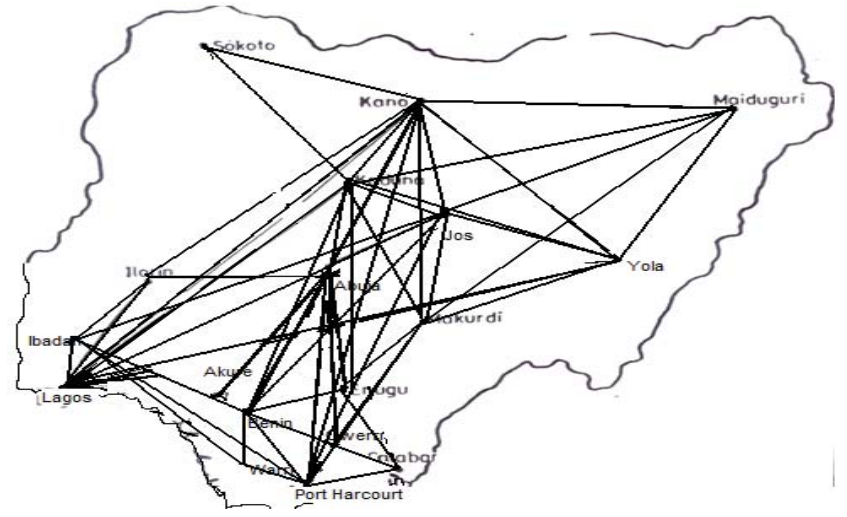

Source: Stephens (2009)

The domestic air transport industry is fast growing when we measure demand for its services. The growth can be attributed to the increased living standard of a few Nigerians as against the general deterioration of an average Nigerian's standard of living. Table 1 showed the revenue generated in the aviation industry as well as the volume of throughput and the National GDP of Nigeria. It further showed the contribution in percentage of GDP. It was discovered that the industry has been making very little impact in terms of contribution to GDP at an average of $0.009011876 \%$, which is what the industry contributes to the GDP. However, one can argue that morally the industry contributes more than that as the influx of Foreign Direct Investment (FDI) has been on the rise with time, of which the investors uses air transport to come around when they do inspections of likely areas of investment choice. Zhang (2001) was of the opinion that FDI contributes to growth of an economy. Amongst other things, availability of a strong air transportation system is a key determinant to the flow of FDI (Wilhelms, 1998).

Table 1: Aviation industry contribution to National GDP

\begin{tabular}{|c|c|c|c|c|}
\hline year & $\begin{array}{c}\text { Revenue in Million } \\
\text { of Naira }\end{array}$ & $\begin{array}{c}\text { Throughput in } \\
\text { passengers }\end{array}$ & $\begin{array}{c}\text { GDP in Million of } \\
\text { Naira }\end{array}$ & $\begin{array}{c}\text { Industry's Share in } \\
\text { percentage of GDP }\end{array}$ \\
\hline 1985 & 95 & 344,208 & $2,937,037.52$ & 0.003234552 \\
\hline 1986 & 187 & 193,649 & $4,353,503.43$ & 0.004295391 \\
\hline 1987 & 174 & 152,877 & $5,769,969.34$ & 0.003015614 \\
\hline 1988 & 146 & 112,105 & $7,186,435.25$ & 0.002031605 \\
\hline 1989 & 106 & 713,336 & $8,602,901.16$ & 0.001232142 \\
\hline 1990 & 78 & 305,617 & $10,019,367.07$ & 0.000778492 \\
\hline 1991 & 57 & 102,101 & $11,435,832.98$ & 0.000498433 \\
\hline 1992 & 26 & 509,819 & $12,852,298.89$ & 0.000202298 \\
\hline 1993 & 104 & 917,538 & $14,268,764.80$ & 0.000727463 \\
\hline 1994 & 484 & $1,325,256$ & $15,685,230.71$ & 0.003088255 \\
\hline 1995 & 803 & $1,732,974$ & $17,101,696.62$ & 0.004696025 \\
\hline 1996 & 996 & $2,140,692$ & $18,518,162.53$ & 0.005377963 \\
\hline 1997 & 1338 & $2,548,411$ & $19,934,628.44$ & 0.006710434 \\
\hline 1998 & 1657 & $2,956,129$ & $21,351,094.35$ & 0.0077626 \\
\hline 1999 & 2072 & $3,363,847$ & $22,767,560.26$ & 0.009101546 \\
\hline 2000 & 2398 & $3,384,262$ & $24,184,026.17$ & 0.009914395 \\
\hline 2001 & 2817 & $4,399,333$ & $25,600,492.08$ & 0.011003304 \\
\hline 2002 & 3304 & $4,831,525$ & $27,016,957.99$ & 0.012230467 \\
\hline 2003 & 3747 & $5,573,101$ & $28,433,423.90$ & 0.013178153 \\
\hline 2004 & 4268 & $6,464,545$ & $29,849,889.81$ & 0.01429955 \\
\hline 2005 & 4817 & $2,744,888$ & $31,266,355.72$ & 0.015406337 \\
\hline
\end{tabular}




\begin{tabular}{|l|l|l|l|l|}
\hline 2006 & 5101 & $7,016,780$ & $32,682,821.63$ & 0.015606976 \\
\hline 2007 & 5481 & $7,174,200$ & $34,099,287.54$ & 0.016073063 \\
\hline 2008 & 5988 & $7,033,311$ & $35,515,753.45$ & 0.016859842 \\
\hline 2009 & 6668 & $7,441,030$ & $36,932,219.36$ & 0.018053342 \\
\hline 2010 & 7410 & $7,848,748$ & $38,348,685.27$ & 0.019322696 \\
\hline 2011 & 7532 & $8,256,466$ & $39,765,151.18$ & 0.018941208 \\
\hline 2012 & 7697 & $8,664,184$ & $41,181,617.09$ & 0.018690378 \\
\hline
\end{tabular}

Source: Nigerian Bureau of Statistics (2013).

7.2 Comparing the Performance of the Nigerian labour force's unitary contribution to the GDP as against the aviation industry

When compared on average worker's contribution to the revenue drive of the industry, one can conveniently say that an average aviation industry worker is doing well and their performance has improved with time from the period the study started to till 2012.

They have been having a significant increase in their level of contribution to the industry's revenue. This can be seen on Table 2. It should be noted too that number of industry-wide employees have been decreasing with time yet the revenue has been on the increase.

Table 2: Workers' performance

\begin{tabular}{|c|c|c|c|c|}
\hline Year & Aviation Employees & Conribution/employee & Nigerian Labour Force & Conribution/employee \\
\hline 1985 & 30,222 & 3.14 & $30,002,921$ & 0.10 \\
\hline 1986 & 32,111 & 5.82 & $29,887,332$ & 0.15 \\
\hline 1987 & 30,122 & 5.78 & $29,000,883$ & 0.20 \\
\hline 1988 & 29,165 & 5.01 & $28,773,625$ & 0.25 \\
\hline 1989 & 30,123 & 3.52 & $28,776,333$ & 0.30 \\
\hline 1990 & 29,405 & 2.65 & $29,746,464$ & 0.34 \\
\hline 1991 & 29,091 & 1.96 & $35,666,625$ & 0.32 \\
\hline 1992 & 28,777 & 0.90 & $39,928,822$ & 0.32 \\
\hline 1993 & 28,462 & 3.65 & $29,888,873$ & 0.48 \\
\hline 1994 & 28,148 & 17.21 & $35,555,525$ & 0.44 \\
\hline 1995 & 27,833 & 28.85 & $37,661,224$ & 0.45 \\
\hline 1996 & 27,519 & 36.19 & $37,666,522$ & 0.49 \\
\hline 1997 & 27,205 & 49.17 & $33,372,622$ & 0.60 \\
\hline 1998 & 26,890 & 61.64 & $35,244,411$ & 0.61 \\
\hline 1999 & 26,576 & 77.97 & $36,545,242$ & 0.62 \\
\hline 2000 & 26,261 & 91.30 & $39,888,762$ & 0.61 \\
\hline 2001 & 25,947 & 108.56 & $46,376,219$ & 0.55 \\
\hline 2002 & 25,633 & 128.91 & $46,598,855$ & 0.58 \\
\hline 2003 & 25,318 & 148.00 & $48,983,733$ & 0.58 \\
\hline 2004 & 25,004 & 170.71 & $49,877,733$ & 0.60 \\
\hline 2005 & 24,689 & 195.10 & $49,746,353$ & 0.63 \\
\hline 2006 & 24,375 & 209.26 & $48,973,522$ & 0.67 \\
\hline 2007 & 24,061 & 227.79 & $48,725,222$ & 0.70 \\
\hline 2008 & 23,746 & 252.16 & $46,583,632$ & 0.76 \\
\hline 2009 & 23,432 & 284.55 & $45,873,532$ & 0.81 \\
\hline 2010 & 23,117 & 320.54 & $44,576,968$ & 0.86 \\
\hline 2011 & 22,803 & 330.31 & $45,326,211$ & 0.88 \\
\hline 2012 & 20,177 & 381.47 & $45,988,887$ & 0.90 \\
\hline
\end{tabular}

Source: Field work (2013)

This is due to the industry's deregulations and the influx of private sector into the industry. With reforms and the withdrawal of the state in the carriage of traffic, many workers previously employed by the state-owned airline were laid- 
off and some absorbed into the privately owned airlines.

Figure 3: Revenue Contribution per Aviation Industry Employee since 1985-2012

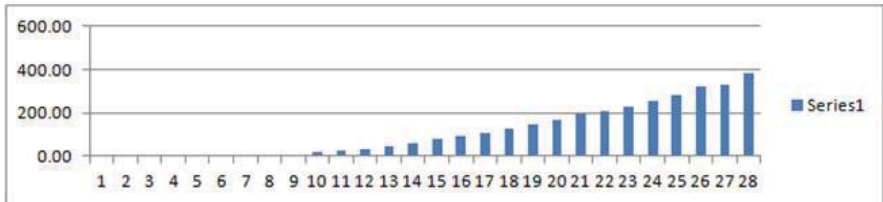

Note that on the X axis in figure 4.3, numbers 1 to 28 represents years 1985 to 2012.

Source: Field Work (2013)

Table 3: Revenue per Throughput.

\begin{tabular}{|c|c|}
\hline year & Revenue/Throughput \\
\hline 1985 & 0.275996 \\
\hline 1986 & 0.965665 \\
\hline 1987 & 1.13817 \\
\hline 1988 & 1.30235 \\
\hline 1989 & 0.148598 \\
\hline 1990 & 0.255221 \\
\hline 1991 & 0.558271 \\
\hline 1992 & 0.050998 \\
\hline 1993 & 0.113129 \\
\hline 1994 & 0.365514 \\
\hline 1995 & 0.463423 \\
\hline 1996 & 0.465223 \\
\hline 1997 & 0.524915 \\
\hline 1998 & 0.560666 \\
\hline 1999 & 0.616021 \\
\hline 2000 & 0.708485 \\
\hline 2001 & 0.640302 \\
\hline 2002 & 0.683904 \\
\hline 2003 & 0.672337 \\
\hline 2004 & 0.660278 \\
\hline 2005 & 1.754899 \\
\hline 2006 & 0.726943 \\
\hline 2007 & 0.76396 \\
\hline 2008 & 0.851363 \\
\hline 2009 & 0.896045 \\
\hline 2010 & 0.9441 \\
\hline 2011 & 0.912255 \\
\hline 2012 & 0.88837 \\
\hline
\end{tabular}

Source: Field Work (2013)

Figure 4: Revenue/GDP Contribution per Nigerian Labour Force since 1985-2012

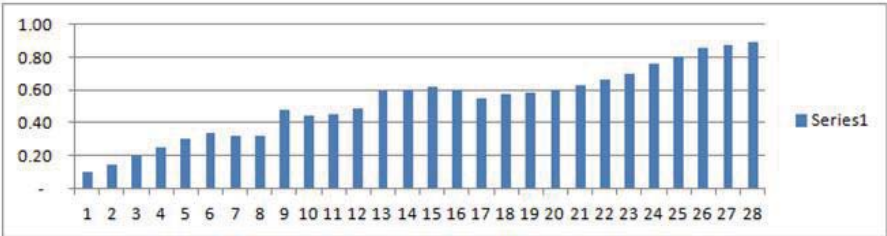

Note that on the X axis in figure 4.4, numbers 1 to 28 represents years 1985 to 2012.

Source: Field Work (2013) 
On the average one can conveniently say an average aviation worker is more productive than an average member of the Nigerian Labour Force (see figures 4.3 and 4.4). However, some will argue that the reason for the large average contribution is because of the luxury nature of air transport and the resultant attached valuation.

\subsection{Growth of the GDP, Aviation Industry and the Workers' contribution}

The fact that air travel is still the safest means of travelling (BBC News, 2000) will continue to make it attractive. Stephens (2009) forecasted that the aviation industry will keep growing at an average of $15 \%$ domestic traffic volume so that by 2019 an estimated 12,461,043 million passengers will be carried domestically. This prediction means that one should expect demand to grow. We tried to verify this by making our own predictions but this time using the aviation industry's revenue and the national GDP as in table 1 to predict into the future the throughput. Then later we used the equation obtained from the regression to do a reverse prediction of what could have happened.

The results are shown for tables 3,4 and 5 below.

$\mathrm{Y}=c+b_{1}\left(\mathrm{X}_{1}\right)+b_{2}\left(\mathrm{X}_{2}\right)+\mathrm{e}$

Where $\quad Y$ is the throughput

$c$ is the intercept

$b_{1}$ is the coefficient of $X_{1}$

$X_{1}$ is revenue of the aviation industry

$b_{2}$ is the coefficient of $X_{2}$

$\mathrm{X}_{2}$ is the national GDP

e captures other conditions

The regression equation is therefore:

$Y=10306851.68+2148.985955\left(X_{1}\right)+1.780119591\left(X_{2}\right)+e$ Equation 1

Table 3: Regression Analysis

\begin{tabular}{|c|c|c|c|c|c|c|}
\hline \multicolumn{2}{|c|}{ Regression Statistics } & & & & & \\
\hline Multiple R & 0.971545568 & & & & & \\
\hline $\mathrm{R}$ Square & 0.943900791 & & & & & \\
\hline Adjusted R Square & 0.939225857 & & & & & \\
\hline Standard Error & 2771633.637 & & & & & \\
\hline Observations & 27 & & & & & \\
\hline \multicolumn{7}{|l|}{ ANOVA } \\
\hline & $D f$ & SS & $M S$ & $\bar{F}$ & Significance $F$ & \\
\hline Regression & 2 & $3.10208 \mathrm{E}+15$ & $1.55104 \mathrm{E}+15$ & 201.9067596 & $9.71585 \mathrm{E}-16$ & \\
\hline Residual & 24 & $1.84367 \mathrm{E}+14$ & $7.68195 \mathrm{E}+12$ & & & \\
\hline \multirow[t]{2}{*}{ Total } & 26 & $3.28644 \mathrm{E}+15$ & & & & \\
\hline & Coefficients & Standard Error & t Stat & $P$-value & Lower 95\% & Upper 95\% \\
\hline Intercept & 10306851.68 & 892889.4367 & 11.54325638 & $2.77886 \mathrm{E}-11$ & 8464018.459 & 12149684.91 \\
\hline$x_{1}$ & 2148.985955 & 722.88773 & 2.972779681 & 0.006619747 & 657.0190089 & 3640.952901 \\
\hline$X_{2}$ & 1.780119591 & 0.655754799 & 2.714611611 & 0.01209425 & 0.426708205 & 3.133530977 \\
\hline
\end{tabular}

Source: Field Work (2013)

Table 4: Predicted Values for Future Throughput

Residual Output

\begin{tabular}{ccc}
\hline Observation & Predicted 2937037.5200001 & Residuals \\
\hline 2013 & 11053430.44 & -6699927.005 \\
2014 & 10952914.58 & -5182945.242 \\
2015 & 10820163.94 & -3633728.689 \\
2016 & 11804466.78 & -3201565.618 \\
2017 & 11018507.91 & -999140.8353 \\
2018 & 10611095.83 & 824737.1494 \\
2019 & 11270264.53 & 1582034.358
\end{tabular}




\begin{tabular}{lcc}
2020 & 12163242.9 & 2105521.895 \\
2021 & 13706934.22 & 1978296.485 \\
2022 & 15117603.31 & 1984093.306 \\
2023 & 16257715.07 & 2260447.458 \\
2024 & 17718025.74 & 2216602.703 \\
2025 & 19130843.81 & 2220250.537 \\
2026 & 20748030.45 & 2019529.808 \\
2027 & 21483866.39 & 2700159.775 \\
2028 & 24191669.08 & 1408822.999 \\
2029 & 26008438.28 & 1008519.708 \\
2030 & 28279888.33 & 153535.5704 \\
2031 & 30987246.54 & -1137356.725 \\
2032 & 25544745.93 & 5721609.787 \\
2033 & 33759106.79 & -1076285.157 \\
2034 & 34855947.88 & -756660.3356 \\
2035 & 35694900.15 & -179146.6973 \\
2036 & 37881138.27 & -948918.908 \\
2037 & 40202547.61 & -1853862.335 \\
2038 & 41190511.16 & -1425359.977 \\
2039 & 42270881.11 & -1089264.016 \\
\hline
\end{tabular}

Source: Field Work (2013)

From the forecast, our prediction was in agreement, to an extent with Stephens' work in 2009. He predicted that by 2019 an estimated 12,461,043 million passengers will be carried domestically whereas our estimate is that 11,270,265 million passengers will be carried by that year. The variation could be due to the fact that ours had better R-Square and adjusted R-Square than his.

Table 5: Predicted Values for Reverse Regression of Throughput

\begin{tabular}{|c|c|c|}
\hline Year & Prediction & Residuals \\
\hline 1977 & 8159409.6 & -54798679 \\
\hline 1978 & 8237580.3 & -53460384 \\
\hline 1979 & 8315751 & -52122089 \\
\hline 1980 & 8393921.7 & -50783793 \\
\hline 1981 & 8472092.5 & -49445498 \\
\hline 1982 & 8550263.2 & -48107203 \\
\hline 1983 & 8628433.9 & -46768908 \\
\hline 1984 & 8706604.6 & -45430613 \\
\hline 1985 & 8784775.3 & -44092317 \\
\hline 1986 & 8862946 & -42754022 \\
\hline 1987 & 8941116.7 & -41415727 \\
\hline 1988 & 9019287.5 & -40077432 \\
\hline 1989 & 9097458.2 & -38739137 \\
\hline 1990 & 9175628.9 & -37400841 \\
\hline 1991 & 9253799.6 & -36062546 \\
\hline 1992 & 9331970.3 & -34724251 \\
\hline 1993 & 9410141 & -33385956 \\
\hline 1994 & 9488311.7 & -32047661 \\
\hline 1995 & 9566482.5 & -30709365 \\
\hline 1996 & 9644653.2 & -29371070 \\
\hline 1997 & 9722823.9 & -28032775 \\
\hline 1998 & 9800994.6 & -26694480 \\
\hline 1999 & 9879165.3 & -25356185 \\
\hline 2000 & 9957336 & -24017889 \\
\hline 2001 & 10035507 & -22679594 \\
\hline 2002 & 10113677 & -21341299 \\
\hline
\end{tabular}




\begin{tabular}{|l|l|l|}
\hline 2003 & 10191848 & -20003004 \\
\hline 2004 & 10270019 & -18664709 \\
\hline 2005 & 10348190 & -17326413 \\
\hline 2006 & 10426360 & -15988118 \\
\hline 2007 & 10504531 & -14649823 \\
\hline 2008 & 10582702 & -13311528 \\
\hline 2009 & 10660872 & -11973233 \\
\hline 2010 & 10739043 & -10634937 \\
\hline 2011 & 10817214 & -9296642.3 \\
\hline 2012 & 10895385 & -7958347.1 \\
\hline
\end{tabular}

Source: Field Work (2013)

The result of reverse regression into the past showed that a large gap existed between the actual past values of throughput and the reverse regression (predicted) values of past throughput. This is not unexpected as the reverse regression values were subjected to the conditions used in the predictions of the future values which might not really represent what actually happened in the past. It can only give a window into what could have happened if the conditions used in the future predictions were available then.

Nigerian airlines could make more revenue by doing more international flights thereby improving the overall GDP of the nation and their own productivity and profitability. The case is further made to be important due to the domination of foreign airlines in some very lucrative routes like Lagos-London, Lagos-Paris and Lagos-Frankfurt of which our flag bearers have very limited presence. Stephens et al (2012) and Nze (2011) stressed the need to encourage local operators to compete on the international scene as a means of boosting growth in the transport sector of the Nigerian economy.

\section{Conclusion}

This study has considered the issue of performance of the aviation workers with regards to their contribution to the National GDP; compare the performance of aviation industry workers with those of the general labour force; ascertain the aviation industry's contribution to the national GDP and did a forecast of the future throughput or demand in the aviation industry. Based on the aforementioned the following summary and finding could be made:

- The industry's contribution to the GDP is very small.

- An average aviation worker contributes per head to the revenue of the industry than an average member of the labour force does to the national revenue or GDP.

- The number of employees engaged in the aviation industry is reducing but the industry is witnessing a boost in productivity of its workers.

- It was also discovered that (though not in the scope of this study) road transport industry contributes more than all the other modes of transport to the GDP.

The present results agreed with the study of Stephens (2009) that the industry will keep experiencing growth of throughput and increased contribution to GDP. Before now it has been a general belief that air transport contributes significantly to the GDP, however, this has been shown to be less than expected and even smaller than the contribution of the road transport industry. In addition we were able to demonstrate that with good understanding of mathematics we can use nearly anything to make good prediction in as much as we can make a regression equation for it, as we used revenue of the aviation industry and the national GDP to predict future demand for air transportation.

\section{References}

BBC News, 8 May (2000). Flying still the safest form of travel. Retrieved January 1, 2010 from http://bbc.co.uk/2/hi/uk news/736582 Ladele, M. (2012). What Are the Impacts of FDI Inflow on Economic Growth of Emerging Economics? (A look at BRICS), an unpublished M. Sc. thesis, submitted to the department of Economics, University of Hulls, UK

Nze, O.N. (2011). Assessment of the Productivity of the Nigerian Shipping Industry an unpublished M.Sc. thesis, submitted to the Transport Management Tech. Dept., Federal University of Tech., Owerri.

Stephens, M.S. (2008). Structure of Air Transport in Nigeria" Unpublished Ph.D. Dissertation. Dept. of Transport Management Technology, Federal University of Technology, Owerri. 
Stephens, M.S. \& Ukpere, W.I. (2011). Airport capacity Utilization in Nigeria: A Performance and Efficiency Analysis, African Journal of Business Management, 5(27): 11104-11115.

Stephens, M.S, Stephens, O., Nze O., Ibe, C.C. \& Ukpere, W.I. (2012). An Assessment of Productivity of Nigerian Shiping Industry Using Saari productivity Model, African Journal of Business Management, 6 (15): 5414-5432.

Wilhelms, S.K.S. (1998). Foreign Direct Investment and its determinants in Emerging Economies, African Economic Policy paper World Bank, World Development Indicators, 2011 Data Bank http://databank.worldbank.org/ddp/home.do, [Online], [Accessed 19 December 2012]

Zhang, K.H. (2001). Does Foreign Direct Investment Promote Economic Growth? Evidence from East Asia and Latin America. Contemporary Economic Policy, 19(2):175-185. 